\title{
THE LIBRARY ASSOCIATION AND ITS BRANCHES.
}

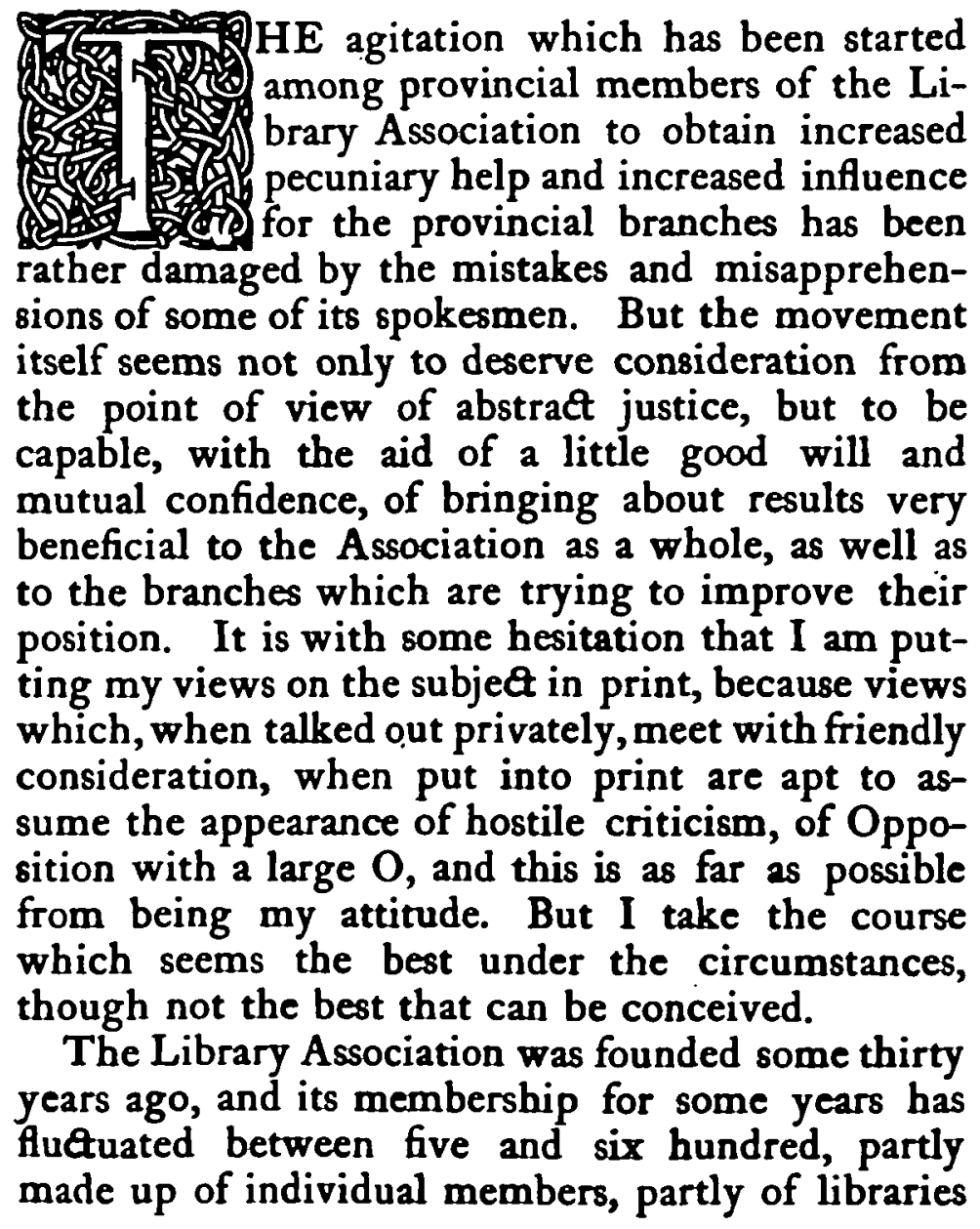


represented by their librarians, or other nominees of the library-committees. Under the influence of the large increase of public libraries brought about by Mr. Carnegie's subsidies, the number of its annual subscribers (it possesses also a considerable body of Life Members) during the years 1902-1905 showed an upward tendency, the income from this source for the four years being successively, $f_{5} 526$ I is. $6 d$., $£ 547$ is., $£ 553$ i 7 s. $6 d$.,$£ 589$ I Is. $6 d$. According to the balance-sheet for 1906, published last May, instead of a continuance of this increase, there was a diminution, the revenue from annual subscriptions falling to $f_{0} 57 \mathrm{I} 4 \mathrm{~s}$. The loss in itself is trifling, but coming at a time when new libraries are continually being opened, it requires explanation. It is the more disconcerting also, because it synchronizes with a sudden and most gratifying leap into success of the educational work at which, with the untiring help of Mr. H. D. Roberts as its secretary for this department, the Association had been toiling painfully year after year without seeming to make much impression. It is certainly a disappointment that just when the younger generation of librarians seem to be shaking off their cherished belief that they can 'do without ' the Association's certificates and diploma, even a slight tendency should evince itself to try to 'do without' membership of the Association.

The advantages which the Library Association offers to its members are of two kinds; (i) corporate, (ii) individual. The corporate advantage consists in the immense improvement in the credit and ${ }_{21}$ status of librarians which the Association has brought 


\section{I 8 THE LIBRARY ASSOCIATION}

about during the thirty years that it has been in existence. It has effected this improvement by steadily holding up the very highest ideals of the work which librarians are able to perform for the community, and by equally steadily insisting on the necessity that those who take up this work shall qualify themselves to carry it out efficiently, and helping them to do so.

It would be a misuse of language to speak of a feature in the history of the Association as 'striking' when, as a matter of fact, it has passed almost if not quite unnoticed, and so a substitute must be found for the word which I was about to use. But it is certainly an extraordinary witness to the enthusiasm of librarians for their work, that the history of the Association may be searched for a whole generation and hardly a trace will be found in it of the urging of any personal pecuniary claims. Librarians are loud in demanding more money for their libraries, but although in proportion to their work they are probably the worst paid body of men and women in the United Kingdom, the questions of salaries and pension schemes with which associations of schoolmasters and schoolmistresses are not infrequently concerned, have hardly ever figured on the agenda paper of either the annual or monthly meetings of the Library Association. The fact, however, remains, that librarians as a class, being miserably underpaid, have very few guineas to spare, and that thus there must be a real temptation in countless cases to take the corporate advantage which the Association has won for all librarians, whether they belong to it or not, as a free gift- 
a matter of course-and to leave the active support of the Association to others.

Thus since human nature, even among librarians, is seldom wholly and continuously unselfish, we are driven to ask what are the advantages which the Association offers to its members individually? The answer is matter of common knowledge. It offers them information as to what librarians are doing, saying and writing all over the world, and more particularly in the English-speaking part of it, and, according to the excellent fashion of combining pleasure and business, it offers opportunities for social intercourse and a certain amount of sightseeing and junketing, to those who can avail themselves of them. What appeal are these advantages likely to make to different classes of members ?

When the Library Association was founded thirty years ago, education in the art of 'thinking imperially' had only reached the stage marked by the acceptance, amid much head-shaking, of Disraeli's enlargement of the Queen's title by the addition of the words Empress of India. The Association's name was thus mainly fixed by the need of distinguishing it from the sister society in the United States of America, and it was styled, I believe, the Library Association of the United Kingdom of Great Britain and Ireland. If it were refounded to-day, it would be difficult for it to avoid calling itself the Library Association of the British Empire, for a glance down its list of members shows addresses from every part of the world under the British flag. Some years ago I was severely reproved by a friend connected with its university for inno- 


\section{0 \\ THE LIBRARY ASSOCIATION}

cently writing of 'far-off Texas.' Texas, I was assured, was not far off, it was quite near the centre; and I meekly accepted the assurance and struck out the obnoxious epithet. After this experience it would show innate unteachability if I picked out one or more places where Library Association members live and work, as examples of isolation amid which any news from more crowded parts of the world would be likely to be specially welcome. But without descending to invidious particulars, it ought to be evident that the fewer fellow librarians a member of the Library Association is likely to meet in the course of a normal year, the more importance will he attach to the possibility of attending an Annual Meeting when he comes to England, and to the monthly refreshment to be obtained from the reports, articles and news in the 'Library Association Record.' May the 'Record' always live up to its imperial opportunities, and may it be generously supported in so doing!

What is obviously true of the worker in one of the smaller libraries in the colonies is true to some extent wherever libraries are sparsely scattered and librarians have few opportunities for personal intercourse. To these scattered units the Annual Meeting and the 'Record' offer an excellent return for a guinea, even when the guinea has been hardly earned. But when the units are not widely scattered, when they are so keen on their work and its interests that they have made themselves opportunities for personal intercourse as abundant as the Association offers to members who live within easy 
reach of Hanover Square, then quite a different situation is created. Then librarians begin to talk about 'taking a real holiday instead of listening to papers at Annual Meetings,' then the 'Record' begins to be criticized, and in an economical fit a librarian may begin to wonder whether his local opportunities are not enough for him, and whether subscription to the Association is really a necessity. $\mathrm{He}$ will be quite wrong if he yields to the temptation; but the temptation exists, and its existence is the cardinal fact in the present situation.

In their gloomier moments secretaries of societies which hold meetings are wont to complain to one another that half of their official life is spent in getting people to read papers, and the other half in getting other people to come to listen to them. The truth which underlies these moanings is that in any society which has its headquarters in London and members in all parts of the world, the proportion of members who live within an hour's journey of the place of meeting is seldom more than 30 per cent., and sometimes considerably lower. Except accidentally, or on a special occasion at the cost of much inconvenience, the great majority of the members never do attend and never will. Two views of this result may be taken. The attending members often consider themselves hardworked individuals, supporting the dignity and interests of the Society at the expense of their personal ease. The non-attending, when they think about the subject at all, mostly regret, mildly or bitterly according to their natures, that they are shut out from the privileges enjoyed by those who ${ }_{21} \cdot$ vIII. 


\section{THE LIBRARY ASSOCIATION}

live in London. That this latter is likely to be the view taken by the non-London members of the Library Association is proved beyond question by the fact that several flourishing provincial branches exist, which in their thirst for such entertainment have organized their own sessions and programmes, and hold meetings for discussion and social intercourse very much like those held at headquarters. The number of members who live in London and the Home Counties at a rough estimate is about I 50; the number of members of the Northern Counties Branch is 104; of the North-Western Branch of the Bristol and Western District, 80; of the Birmingham and District, 43. For the North Midland Branch I have no figures. The proportion of members of these branches who are also members of the central body varies considerably. But it is evident that the total membership of several of the branches is sufficiently large to make their meetings very much on a level with those at Hanover Square. The expenses of the monthly meetings at Hanover Square are borne by the whole Association. The expenses of each branch meeting had at first to be borne by its own members. Latterly a grant of two shillings a head has been made to branches for each Library Assuciation member on their rull. This, of course, only suffices to pay for notices and postage, and thus a member of the Library Association who belongs to an active provincial branch has to pay two subscriptions (less two shillings), where a London member only pays one.

This is the first grievance of the provincial branches, and the second is like unto it. When the 
individual members of a branch are keen and enthusiastic, a natural desire springs up that the opinion of the branch should have some weight in determining the action of the Association on questions of library policy. At the Annual Meetings London and the provinces are all equal. During the rest of the year the provinces have a paper majority on the Council of 20 to 12 . But as librarians have little time and less money, the provincial councillors attend the Council meetings very seldom, and the management from one Annual Meeting to another is exclusively in the hands of the officials, mostly Londoners, and of the twelve London members of Council. I am afraid that many provincial members believe that the London members delight that this is so. I am quite sure that the Council would be glad if its meetings were more representative. But there are two difficulties in securing the attendance of country councillors; first, that attendance costs money, and if travelling and hotel expenses had to be allowed to each of twenty provincial councillors at every monthly meeting of the Council, not to mention those of committees, they might easily run to several hundred pounds a year. In the second place, if attendance is only given for special reasons, business may be postponed from one meeting to another, so that a councillor from Manchester may have to attend several meetings to see the end of a particular question.

Thus it seems that there is at present a very considerable temptation for a provincial librarian to say to himself: 'I can get all the social intercourse, 


\section{THE LIBRARY ASSOCIATION}

all the discussion and professional talk that I want, by membership of my local branch; why should I pay an extra nineteen shillings to help to defray the expenses of the London meetings, while I have practically no prospect of being able to take a part in the work of the Association? The representation is a farce; the taxation is excessive. I shall save my nineteen shillings.' Whatever excuse may be found for saying it, this is emphatically not the right thing to say, but that something very like it is being said or thought can be proved in a moment.

Of the 93 members of the North-Western Branch, no fewer than 79-all honour to them!-are members of the Association. But the story of the other branches is very different. Of the 104 members of the Northern Counties, only 20 support the Association; of the 43 members of the Birmingham Branch, only 15 ; of the 80 members of the Bristol Branch, only I 3. As already stated, I have no figures for the North Midland Branch, but $I$ believe that the proportion is about the same as at Bristol. I think the situation may be fairly stated by saying that the North-Western Branch has persuaded its members to belong to the Library Association and to fight for better treatment, while the other branches are content that the great majority of their members should "do without "membership of the central body.

The question of the moment is which policy is to prevail. Is the North-Western Branch to be discouraged till it allows the members to drop away from the central body, or are the other 
branches to be encouraged to put pressure on their members to imitate the good example of the NorthWestern? As one who wants the Association to grow stronger rather than weaker, I have no hesitation in saying that it is the North-Western Branch which must be taken as a standard, and the only question is how can the necessary encouragement be given. How can these difficulties as to money and representation be overcome?

It is quite clear that, if the Association is to thrive, membership of the Association must carry with it membership of the branch. It is against all reason and justice that members in Birmingham, Bristol, or Manchester should have to pay two subscriptions for the same privileges for which London members only pay one. But it is quite clear also that if the Association is to make increased grants to the branches, the branches must help the Association to get more money by increased membership. Cannot this be done by exciting a little healthy competition? It has already been suggested that members in districts where libraries are few derive far more benefit from the central Association than those whose opportunities for intercourse are abundant. It is also obvious that a strong branch has more need of money than a weak one, since its very strength involves more elaborate meetings, the development of educational classes and the desire to pay the expenses of provincial councillors in order to enable them to attend meetings of Council when important business is to be transacted. It is the strong branches, therefore, which have to be encouraged, and the Association is justified in taking 


\section{THE LIBRARY ASSOCIATION}

as its test of strength the number of members of the branch who are also members of the Association. There seems nothing unreasonable in suggesting that for a branch to be subsidized by the Association at least one-fortieth ( $2 \frac{1}{2}$ per cent.) of the members of the Association should belong to it, and that for every additional $2 \frac{1}{2}$ per cent. of the total membership which it can show, the subsidy should be increased. Taking the total present membership roughly at 600 , one fortieth, or $2 \frac{1}{2}$ per cent., of this will be I 5. Why should not a branch which includes 15 Association members be granted, as at present, 2s. capitation on each of these; a branch which includes 30 Association members, 3 s.; a branch which contains 45,45 , and so on by increases of a shilling for every 15 members until a branch with I 35 receives IOs., or by a final advance of sixpence a maximum capitation of ros. $6 \mathrm{~d}$. is earned by one of I 50? Such a system would provide the leverage which is conspicuously absent at present. A branch with less than I5 Association members would speedily raise itself to that number; a branch with 25 members would speedily raise itself to 30 . At present there are some two hundred members of branches not members of the Association. If only 50 of these took up membership, the Association would be able to pay the grants on the scale advocated, and have at least $f \mathrm{r} 0$, possibly as much as $£ 25$, in hand for the extra expense entailed by its 50 new members. If any larger increase than 50 were obtained the result would be still more satisfactory.

There is a certain sporting element in this scheme 
which might conceivably make it a great success. If it is thought too elaborate, the Association might be well content to increase the capitation grant to the branches from two shillings to five, conditionally on the branches exerting themselves to obtain fifty new members. But it seems more reasonable that a branch like the North Western, which has persuaded the great bulk of its branchmembers to take the patriotic course, should receive special encouragement, than that all branches should be treated alike.

The extra income from the parent Association would in most cases be counterbalanced by the remission of the branch subscriptions of members of that body. It would need a larger capitation than five shillings to enable the branches to defray the travelling expenses of one or more provincial councillors as regular attendants at Council meetings. The difficulty, moreover, would still remain that the agenda at many of these meetings would continue to be concerned with purely London matters, as to which a provincial councillor would have no reason to intervene. The question is thus raised whether there is any valid reason against separating the two classes of business, that which concerns the Association as a whole and that of purely London interest. I must own that as a devout Londoner when I first read a reference to 'the London branch' in a provincial onslaught on the Council, it seemed little short of lese majesté. But on recovering from the shock (which, after all, was no worse than that caused by a late reference to the British Museum as 'the Bloomsbury institution ') 


\section{THE LIBRARY ASSOCIATION}

the advantages to London of having a branch seemed very well worth considering. A London branch would, of course, include the Home Counties, and it would thus start at once with upwards of $150 \mathrm{mem}$ bers. On the scheme here advocated it would have an income quite sufficient for its needs. On the basis of a five shillings capitation fee, it would need either an increased number of Association members or an influx of branch members on a lower scale, which would probably be more easily obtained. The appointment of a separate honorary secretary for the branch would relieve the Association's honorary secretary of a considerable part of his work, while the separation of London business from Association business would enable the Association's Council to get through its work with fewer meetings, and thus allow provincial councillors to attend regularly at a less expense of time and money. The proposal seems at first sight revolutionary. In reality it is not a revolution, but the recognition of a revolution which has already been brought about by the vigorous growth of the provincial branches.

On a very small scale, the Library Association seems to be brought face to face with the identical problems on the right solution of which hangs the future of the British Empire. Its children have grown up. Will those who have managed the affairs of the Association so faithfully and so successfully in the past face the new situation thus created, or will they shut their eyes, and try to treat their vigorous offspring as still children, who must be content to have their affairs managed for them? The one great step forward made in the 
late Imperial Conference was the recognition that it was a Conference of the Prime Ministers of the constituent states of the Empire, no longer mere nurselings of the Colonial Office. Our own little crisis is happily not quite so complex as that with which I have ventured to compare it. But it needs for its solution the same spirit of give-and-take, the same readiness to recognize new facts on the one side, and the same patience and absence of suspicion on the other. Only a faint-heart can doubt that the British Empire is going to worry through, and evolve itself into a federation of free states greater than the world has yet seen, and I am confident that London and the provincial branches when they face facts squarely will infuse new vigour into the Library Association, and send up its membership to over a thousand.

Alfred W. Pollard. 